\title{
C-Reactive Protein, Procalcitonin, Clinical Pulmonary Infection Score, and Pneumonia Severity Scores in Nursing Home Acquired Pneumonia
}

\author{
Ilias Porfyridis MD PhD, Georgios Georgiadis MD PhD, Paris Vogazianos PhD, \\ Georgios Mitis, and Andreas Georgiou MD PhD
}

\begin{abstract}
BACKGROUND: Patients with nursing home acquired pneumonia (NHAP) present a distinct group of lower respiratory track infections with different risk factors, clinical presentation, and mortality rates. OBJECTIVES: To evaluate the diagnostic value of clinical pulmonary infection score (CPIS), C-reactive protein, and procalcitonin and to compare the accuracy of pneumonia severity scores (confusion, urea nitrogen, breathing frequency, blood pressure, $\geq 65$ y of age [CURB-65]; pneumonia severity index; NHAP index; systolic blood pressure, multilobar involvement, albumin, breathing frequency, tachycardia, confusion, oxygen, arterial pH [SMART-COP]; and systolic blood pressure, oxygen, age $>65 \mathrm{y}$, breathing frequency [SOAR]) in predicting inpatient mortality from NHAP. METHODS: Nursing home residents admitted to the hospital with acute respiratory illness were enrolled in the study. Subjects were classified as having NHAP (Group A) or other pulmonary disorders (Group B). Clinical, imaging, and laboratory data were assessed to compute CPIS and severity scores. C-reactive protein and procalcitonin were measured by immunonephelometry and immunoassay, respectively. RESULTS: Fifty-eight subjects were diagnosed with NHAP (Group A) and 29 with other pulmonary disorders (Group B). The mean C-reactive protein \pm SD was $16.38 \pm 8.6 \mathrm{mg} / \mathrm{dL}$ in Group A and $5.2 \pm 5.6 \mathrm{mg} / \mathrm{dL}$ in Group B $(P<.001)$. The mean procalcitonin \pm SD was $1.52 \pm 2.75 \mathrm{ng} / \mathrm{mL}$ in Group A and $0.24 \pm 0.21 \mathrm{ng} / \mathrm{mL}$ in Group B $(P=.001)$. The mean CPIS \pm SD was $5.4 \pm 1.2$ in Group A and $2.3 \pm 1.5$ in Group B $(P<.001)$. At a cutoff value of $0.475 \mathrm{ng} / \mathrm{mL}$, procalcitonin had a sensitivity of $83 \%$ and a specificity of $72 \%$. At a cutoff value of $8.05 \mathrm{mg} / \mathrm{dL}, \mathrm{C}$-reactive protein had a sensitivity of $81 \%$ and a specificity of 79\%. Procalcitonin and C-reactive protein levels were significantly higher in Grampositive NHAP. The in-patient mortality was $17.2 \%$ in Group A. Procalcitonin levels were $4.67 \pm 5.4 \mathrm{ng} / \mathrm{mL}$ in non-survivors and $0.86 \pm 0.9 \mathrm{ng} / \mathrm{mL}$ in survivors $(P<.001)$. The area under the curve for procalcitonin in predicting in-patient mortality was $0.84(95 \% \mathrm{CI} 0.70-0.98, P=.001)$. A procalcitonin level upon admission $>1.1 \mathrm{ng} / \mathrm{mL}$ was an independent predictor of in-patient mortality. Of the pneumonia severity scores, CURB-65 showed greater accuracy in predicting in-patient mortality (area under the curve of $0.68,95 \%$ CI $0.53-0.84, P=.06$ ). CONCLUSIONS: CPIS, procalcitonin, and C-reactive protein are reliable for the diagnosis of NHAP. Procalcitonin and CURB-65 are accurate in predicting in-patient mortality in NHAP. Key words: geriatrics/elderly patients/aging; infections/infectious diseases/infection control; pneumonia; severity of illness/scoring system. [Respir Care 2014;59(4):574-581. (C) 2014 Daedalus Enterprises]
\end{abstract}

\section{Introduction}

Nursing home acquired pneumonia (NHAP) is the leading cause of hospitalization, morbidity, and mortality

\footnotetext{
Drs Porfyridis, Georgiadis, Vogazianos, and Georgiou are affiliated with the Pulmonary Department, and Mr Mitis is affiliated with the Immunology Department, Nicosia General Hospital, Nicosia, Cyprus.
}

The authors have disclosed no conflicts of interest. among nursing home residents, with different clinical presentation and causative pathogens from community acquired pneumonia (CAP). ${ }^{1}$ Nursing home residents usually have comorbidities, such as heart failure, chronic

\footnotetext{
Dr Porfyridis presented part of this paper at the European Respiratory Society Annual Congress, held September 25, 2011, in Amsterdam, The Netherlands.
} 
respiratory diseases, cognitive impairment, advanced age, poor functional status, history of alcoholism, and use of immunosuppressants, which make the diagnosis of NHAP a challenge because clinical and laboratory signs are neither sensitive nor specific enough, and microbiological studies often remain negative. Moreover, these subjects have unique risk factors for colonization with resistant pathogens. Hospitalization rates for NHAP vary from $15 \%$ to $46 \%$, and mortality rates range from $5 \%$ to $40 \% .^{2}$

Many biomarkers, such as leukocyte count, C-reactive protein, and procalcitonin, have been found to play a role in the early diagnosis and prognosis of pneumonia, especially CAP and ventilator-associated pneumonia (VAP). ${ }^{3-6}$ In addition, clinical infection scores, such as the clinical pulmonary infection score (CPIS), have been evaluated in the early diagnosis of VAP and $\mathrm{CAP}^{6,7}$ However, there are only limited data on NHAP.

Assessment of the disease severity is an important early step in the management of patients. Several severity scoring systems have been used to predict prognosis of pneumonia. The accuracy of the confusion, urea nitrogen, breathing frequency, blood pressure, $\geq 65$ y of age (CURB-65) score and its modifications (CRB-65) and the pneumonia severity index are the most commonly used prediction rules in clinical practice. ${ }^{3,8-10}$ More recently, proposed scoring systems, such as systolic blood pressure, multilobar involvement, albumin, breathing frequency, tachycardia, confusion, oxygen, arterial $\mathrm{pH}$ (SMART-COP) ${ }^{11}$ and systolic blood pressure, oxygen, age $>65 \mathrm{y}$, breathing frequency (SOAR), ${ }^{9}$ have appeared to be useful in the prognosis of CAP and pneumonia in elderly patients. Also, the NHAP index has been used to predict mortality in NHAP. ${ }^{12}$ However, the accuracy of these prediction rules has not been compared in subjects hospitalized with NHAP.

The aim of the present study was to evaluate the diagnostic and prognostic value of CPIS, C-reactive protein, and procalcitonin in predicting in-patient mortality for patients diagnosed with NHAP. In addition, we aimed to compare the accuracy of pneumonia severity scores in this group of patients.

\section{Methods}

In this observation trial, all nursing home residents admitted to the Pulmonary Department at Nicosia General Hospital in Nicosia, Cyprus, with acute respiratory illness from November 2010 to January 2012 were evaluated for

Correspondence: Ilias Porfyridis MD PhD, Pulmonary Department, Nicosia General Hospital, 215 Nicosia-Limassol Old Road, Strovolos 2029, Nicosia, Cyprus. E-mail: ilias_porfi@yahoo.gr.

DOI: $10.4187 /$ respcare.02741

\section{QUICK LOOK}

\section{Current knowledge}

Patients with nursing home acquired pneumonia (NHAP) represent a distinct group of lower respiratory tract infections with different risk factors, clinical presentation, and mortality rates.

\section{What this paper contributes to our knowledge}

The clinical pulmonary infection score, C-reactive protein, and procalcitonin reliably diagnose NHAP.

participation. Inclusion criteria were (1) age $>16 \mathrm{y}$, (2) nursing home residence, (3) written informed consent, and (4) acute respiratory illness. Exclusion criteria were (1) human immunodeficiency virus (HIV) infection, (2) documented extrapulmonary infection, (3) neutropenia, and (4) oral intake of corticosteroids (defined as $>1 \mathrm{mg} / \mathrm{kg}$ prednisone for $>1 \mathrm{mo}$ ) or chemotherapy during the previous $90 \mathrm{~d}$. The study protocol was approved by the Bioethics Committee of the Cyprus Government, and written informed consent was obtained from all subjects or their relatives within the first $12 \mathrm{~h}$ after admission.

Clinical, laboratory, and imaging data were recorded immediately after admission for each subject, including (1) past medical history and clinical presentation, (2) prior use of antibiotics and/or steroids, (3) body temperature, (4) arterial blood gases, (5) peripheral blood cell counts, (6) Gram stains and cultures of all biological fluids obtained (blood, sputum, bronchial secretions, bronchoalveolar lavage, and pleural fluid), (7) imaging findings, and (8) antigen serology (Legionella pneumophila and Streptococcus pneumonia urinary antigen). The functional status of each subject before admission was assessed according to the Eastern Cooperative Oncology Group score, ${ }^{13}$ which runs from 0 to 5 , with 0 denoting perfect health and 5 indicating death. CPIS, which combines the following 6 variables (tracheal secretions, chest $\mathrm{x}$-ray infiltrates, body temperature, white blood cell (WBC) count, oxygenation $\left[\mathrm{P}_{\mathrm{aO}_{2}} / \mathrm{F}_{\mathrm{IO}_{2}}\right.$ ratio], and microbiology from tracheal secretions), was calculated and recorded. ${ }^{14}$

The diagnosis of NHAP was made according to current guidelines and recommendations. ${ }^{15,16} \mathrm{NHAP}$ was defined by the following criteria observed at initial presentation or within $24 \mathrm{~h}$ after hospitalization: admission from a nursing home, the presence of a new radiographic pulmonary infiltrate, and acute onset of at least 2 clinical or biological findings suggestive of pneumonia (cough, sputum production, fever, shortness of breathing, pleuritic chest pain, altered mental status, pulmonary consolidation on physical examination, and total leukocyte count $>12,000 / \mathrm{mm}^{3}$ or $<4,000 / \mathrm{mm}^{3}$ ). The severity of pneumonia was assessed 
immediately after admission by calculating CURB- $65,{ }^{3}$ pneumonia severity index, ${ }^{3}$ NHAP index (breathing frequency of $>30 / \mathrm{min}$, heart rate of $>125$ beats $/ \mathrm{min}$, confusion, and dementia), ${ }^{12}$ SMART-COP, ${ }^{11}$ and SOAR $^{9}$ scoring systems.

Pneumonia was considered to be absent either when an alternative cause for pulmonary infiltrate was established (eg, pulmonary embolus) or when there were no new pulmonary infiltrates in radiological images.

Serum C-reactive protein and procalcitonin were assessed within $12 \mathrm{~h}$ of hospital admission. C-reactive protein was measured by immunonephelometry in serum using an automated analyzer (BN ProSpec, Siemens, Berlin, Germany) and was expressed in $\mathrm{mg} / \mathrm{dL}$, whereas procalcitonin was assessed using a procalcitonin immunoassay kit (Brahms GmbH, Hennigsdorf, Germany) in a Brahms Kryptor immunoassay system and was expressed in $\mathrm{ng} / \mathrm{mL}$ following the manufacturer's instructions.

All cases were evaluated by 2 clinicians, and agreement about the diagnosis was achieved in all cases. Subjects were divided in 2 groups: Group A included subjects diagnosed with NHAP, and Group B included subjects diagnosed with other pulmonary disorders. In-hospital mortality for each group was also recorded.

\section{Statistical Analysis}

Values are presented as mean $\pm \mathrm{SD}$. Comparisons between groups were made using chi-square test (testing for the null hypothesis that the relative proportions of the variable are independent of the group, and thus, changing the group will not significantly change the proportions of the dependent variable) and paired samples $t$ test (testing for the null hypothesis that the difference is not significantly different from zero vs the alternative hypothesis that the difference is significantly different from zero). Probability values $<5 \%(P<.05)$ were considered statistically significant. Receiver operating characteristic (ROC) curves were also designed to assess sensitivity, specificity, and positive and negative predictive values for the estimated parameters. Survival was assessed by Kaplan-Meier analysis, and comparisons were drawn by log-rank test. All statistics and graphs were prepared using the statistical software (SPSS 17.0.0, SPSS, Chicago, Illinois).

\section{Results}

Eighty-seven subjects were included in the study. Demographic characteristics and clinical and laboratory data of the study population are summarized in Table 1 .

Group A $(n=58)$ consisted of subjects with NHAP. Twenty-seven had microbiological evidence of pulmonary infection based upon positive cultures from sputum, blood, or bronchoalveolar lavage samples (when bronchoscopy was performed). The rest were diagnosed with NHAP based on clinical and radiological presentation and a good response to antibiotic therapy. The clinical presentation and the comorbidities of subjects in Group A are presented in Table 1. The main radiological findings consisted of right pulmonary infiltrates in 33 subjects ( 2 with combined pleural effusion), left pulmonary infiltrates in 20 subjects (one with combined pleural effusion), and bilateral lung infiltrates in 5 subjects. Thirty-one subjects $(53.4 \%)$ were diagnosed with aspiration pneumonia.

Group B $(n=29)$ consisted of subjects with other pulmonary disorders, most of them with clinical presentation simulating chest infection at admission. The diagnoses, clinical presentation, and comorbidities of subjects in Group $\mathrm{B}$ are also presented in Table 1. In radiological imaging, 4 subjects presented bilateral pulmonary infiltrates or pleural effusions, 5 subjects presented left pulmonary infiltrates or pleural effusion, and 4 subjects presented right pulmonary infiltrates. Finally, no significant pathologic findings were observed in chest $\mathrm{x}$-ray images in 16 cases.

In $18 \%$ of cases with pathological findings in chest x-ray images, an alternative cause for pulmonary infiltrate was established. The accuracy of clinical characteristics at presentation (ie, fever, shortness of breath, and cough) showed an area under the curve of 0.59 (95\% CI $0.47-$ $0.72, P=.15)$. The addition of a raised WBC count of $>12,000 / \mathrm{mm}^{3}$ showed a similar area under the curve, 0.59 (95\% CI 0.48-0.72, $P=.15$ ) (Fig. 1).

CPIS upon admission and after $48 \mathrm{~h}$ and the concentrations of C-reactive protein and procalcitonin in the sera of both groups are also given in Table 1. All 4 parameters were significantly higher in Group A than in Group B.

ROC curves for CPIS, C-reactive protein, and procalcitonin for the diagnosis of NHAP are shown in Figure 2. The area under the curve for procalcitonin was 0.82 (95\% CI $0.73-0.9, P=.001$ ), and that for C-reactive protein was 0.87 (95\% CI $0.8-0.95, P=.001)$. The area under the curve for CPIS upon admission and that after $48 \mathrm{~h}$ were $0.93(95 \% \mathrm{CI} 0.8-0.9, P=.001)$ and 0.95 (95\% CI $0.9-0.99, P=.001)$, respectively. At a cutoff value of $0.475 \mathrm{ng} / \mathrm{mL}$, procalcitonin had a sensitivity of $83 \%$, a specificity of $72 \%$, a positive predictive value of $86 \%$, and a negative predictive value of $68 \%$. At a cutoff value of $8.05 \mathrm{mg} / \mathrm{dL}$, C-reactive protein had a sensitivity of $81 \%$, a specificity of $79 \%$, a positive predictive value of $88 \%$, and a negative predictive value of $67 \%$ for the diagnosis of NHAP.

Among all subjects (Groups A and B), the mean C-reactive protein $\pm \mathrm{SD}$ was $16.8 \pm 8.5 \mathrm{mg} / \mathrm{dL}$ for culturepositive and $10.9 \pm 9.2 \mathrm{mg} / \mathrm{dL}$ for culture-negative $(P=.006)$. The mean procalcitonin $\pm \mathrm{SD}$ was $2.5 \pm 3.8$ $\mathrm{ng} / \mathrm{mL}$ for culture-positive and $0.5 \pm 0.42 \mathrm{ng} / \mathrm{mL}$ for culture-negative $(P<.001)$. Figure 3 shows the relationships 
Pneumonia Severity Scores in Nursing Home Acquired Pneumonia

Table 1. Demographic and Clinical Characteristics of 87 Subjects Enrolled in This Study

\begin{tabular}{|c|c|c|c|}
\hline & Group A $(n=58)$ & Group B $(n=29)$ & $P$ \\
\hline Age, mean \pm SD y & $79.6 \pm 15.4$ & $79.8 \pm 6.3$ & .95 \\
\hline Male/female & $35 / 23$ & $19 / 10$ & \\
\hline \multirow[t]{7}{*}{ Comorbidities $(n)$} & Congestive heart failure (26) & Congestive heart failure (15) & \\
\hline & Chronic respiratory diseases (9) & Chronic respiratory diseases (18) & \\
\hline & Chronic renal failure (6) & Chronic renal failure (6) & \\
\hline & Psychiatric disease (10) & Cognitive impairment (10) & \\
\hline & Cognitive impairment (41) & & \\
\hline & Gastrostomy (4) & & \\
\hline & Tracheostomy (3) & & \\
\hline \multirow[t]{8}{*}{ Diagnoses $(n)$} & NHAP (58) & Lung cancer (3) & \\
\hline & Streptococcus pneumoniae (8) & Pulmonary embolism (4) & \\
\hline & Staphylococcus aureus (4) & Congestive heart failure (7) & \\
\hline & Haemophilus influenzae (4) & Bronchial asthma exacerbation (2) & \\
\hline & Pseudomonas aeruginosa (5) & COPD exacerbation (10) & \\
\hline & Other (8) & Usual interstitial pneumonia (2) & \\
\hline & Mixed infection (2) & & \\
\hline & No known pathogen (31) & & \\
\hline Fever $\left(>37.8^{\circ} \mathrm{C}\right), n(\%)$ & $38 / 65.5$ & $10 / 34.4$ & .006 \\
\hline Fever, shortness of breathing, and cough, $n(\%)$ & $25 / 42.3$ & $7 / 24.1$ & .084 \\
\hline $\mathrm{PS}$, mean $\pm \mathrm{SD}$ & $3.6 \pm 0.8$ & $2.86 \pm 1.026$ & .002 \\
\hline $\mathrm{P}_{\mathrm{O}_{2}} / \mathrm{F}_{\mathrm{IO}_{2}}$, mean $\pm \mathrm{SD}$ & $221.6 \pm 77.07$ & $250.3 \pm 59.1$ & .06 \\
\hline $\mathrm{CPIS}$, mean $\pm \mathrm{SD}$ & $5.4 \pm 1.2$ & $2.3 \pm 1.5$ & $<.001$ \\
\hline CPIS at $48 \mathrm{~h}$, mean $\pm \mathrm{SD}$ & $6.16 \pm 1.7$ & $2.3 \pm 1.5$ & $<.001$ \\
\hline White blood cell count, mean $\pm \mathrm{SD}$ cells $/ \mathrm{mm}^{3}$ & $15,480.75 \pm 6,299$ & $11,131 \pm 4,944$ & .002 \\
\hline $\mathrm{PCT}$, mean $\pm \mathrm{SD} n g / \mathrm{mL}$ & $1.5 \pm 2.8$ & $0.2 \pm 0.2$ & .001 \\
\hline $\mathrm{CRP}$, mean $\pm \mathrm{SD} \mathrm{mg} / \mathrm{dL}$ & $16.4 \pm 8.6$ & $5.2 \pm 5.6$ & $<.001$ \\
\hline $\begin{array}{l}\text { NHAP = nursing home acquired pneumonia } \\
\text { PS = performance status } \\
\text { CPIS = clinical pulmonary infection score } \\
\text { PCT = procalcitonin } \\
\text { CRP = C-reactive protein }\end{array}$ & & & \\
\hline
\end{tabular}

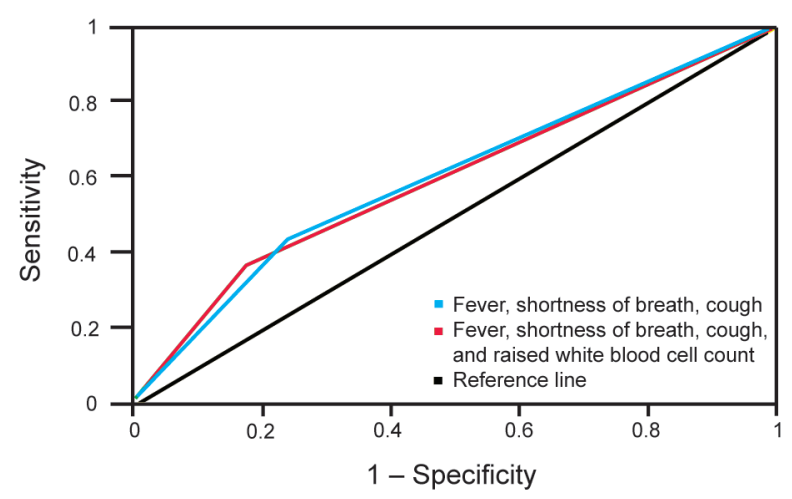

Fig. 1. Receiver operator characteristic curve of clinical symptoms at presentation for the diagnosis of nursing home acquired pneumonia.

between serum C-reactive protein and procalcitonin levels and the identified causative pathogen of NHAP in Group A. Mean C-reactive protein \pm SD levels were $22.2 \pm 8.9$ $\mathrm{mg} / \mathrm{dL}$ in NHAP cases caused by Gram-positive pathogens and $13.6 \pm 6.4 \mathrm{mg} / \mathrm{dL}$ in NHAP cases caused by Gram- negative pathogens $(P=.007)$, whereas mean procalcitonin \pm SD levels were $4.1 \pm 5.1 \mathrm{ng} / \mathrm{mL}$ in Gram-positive NHAP cases compared with $1.6 \pm 2.4 \mathrm{ng} / \mathrm{mL}$ in Gramnegative NHAP cases $(P=.09)$.

In-patient mortality in Group A was $17.2 \%$. The means \pm SD for C-reactive protein, procalcitonin, and pneumonia severity scores of survivors and non-survivors in Group A are presented in Table 2. Procalcitonin and CURB-65 were significantly greater among non-survivors $(P<.001$ and $P=.034$, respectively). The accuracy of C-reactive protein to predict in-patient mortality showed an area under the curve of 0.63 (95\% CI $0.43-0.84, P=.2$ ), whereas the accuracy of procalcitonin was better, with an estimated area under the curve of 0.84 (95\% CI $0.7-0.98, P=.001$ ) (Fig. 4). A threshold procalcitonin value of $1.1 \mathrm{ng} / \mathrm{mL}$ achieved a sensitivity of $80 \%$ and a specificity of $82 \%$ in predicting in-patient mortality. A survival analysis using Kaplan-Meier curves and the log-rank test demonstrated that procalcitonin serum levels upon admission of $<1.1 \mathrm{ng} / \mathrm{mL}$ were associated with better survival (log- 

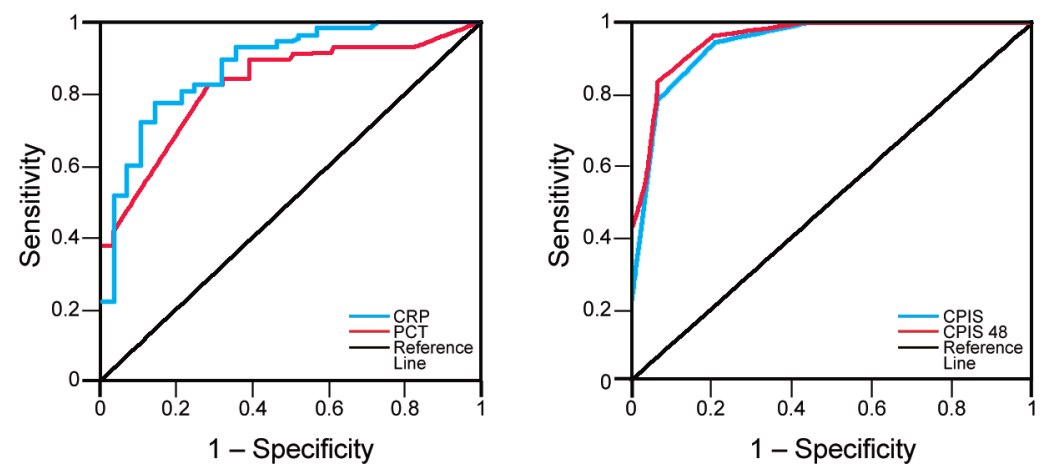

Fig. 2. Left - receiver operator characteristic curve of C-reactive protein (CRP) and procalcitonin (PCT). Right - receiver operator characteristic curve of clinical pulmonary infection score (CPIS) at admission and CPIS after $48 \mathrm{~h}$ for the diagnosis of nursing home acquired pneumonia.
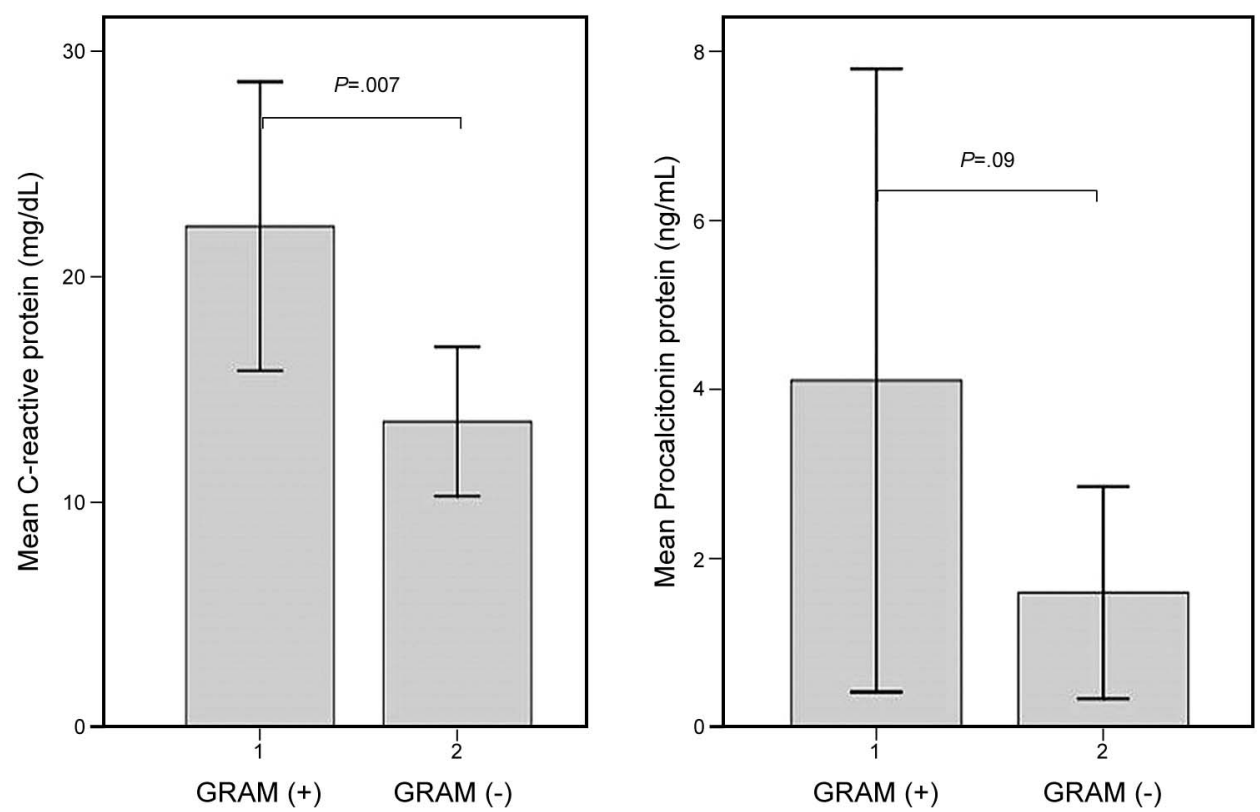

Fig. 3. Subjects with nursing home acquired pneumonia (NHAP; Group A). Subjects are divided into two subgroups: $1=$ Gram-positive NHAP; 2 = Gram-negative NHAP. Left: Serum levels of C-reactive protein. Right: Serum levels of procalcitonin.

rank test, $P<.001$ ) (Fig. 5). From the statistical analysis, no similar threshold value was found for WBC count, C-reactive protein, or CURB-65. CURB-65 showed better accuracy in predicting in-patient mortality (area under the curve of $0.68,95 \%$ CI $0.53-0.84, P=.06$ ) compared with other pneumonia severity scores. The areas under the curve for the other pneumonia severity scores were: pneumonia severity index, 0.65 (95\% CI $0.49-0.82, P=.12$ ); NHAP index, 0.58 (95\% CI 0.41-0.75, $P=.41)$; SMART-COP, 0.57 (95\% CI $0.36-0.78, P=.45$ ); and SOAR, 0.62 (95\% CI 0.42-0.82, $P=.23$ ) (Fig. 6).

\section{Discussion}

To our knowledge, this is the first study to evaluate and compare the diagnostic and prognostic accuracy of procalcitonin, C-reactive protein, CPIS, and pneumonia severity scores in NHAP. The results of the present study indicate that CPIS and serum procalcitonin and C-reactive protein are reliable markers for the early diagnosis of NHAP. The serum levels of C-reactive protein and procalcitonin were found to be higher in NHAP cases caused by Gram-positive pathogens compared with Gram-negative pathogens; however, CPIS scores did not follow a similar trend. Procalcitonin appeared to have greater accuracy in predicting in-hospital mortality from NHAP than pneumonia severity scores. CURB-65 and the pneumonia severity index performed better than the other proposed severity scoring systems. Procalcitonin serum levels of $>1.1 \mathrm{ng} / \mathrm{mL}$ upon admission were an accurate independent predictor of in-hospital mortality from NHAP. 
Table 2. CRP, Procalcitonin, and Pneumonia Severity Scores of 58 Subjects With NHAP

\begin{tabular}{|c|c|c|c|}
\hline & $\begin{array}{c}\text { Survivors } \\
\text { (Mean } \pm \text { SD) }\end{array}$ & $\begin{array}{l}\text { Non-survivors } \\
\text { (Mean } \pm \text { SD) }\end{array}$ & $P$ \\
\hline CRP (mg/dL) & $15.6 \pm 7.9$ & $19.96 \pm 10.9$ & .14 \\
\hline PCT (ng/mL) & $0.9 \pm 0.9$ & $4.7 \pm 5.4$ & $<.001$ \\
\hline CURB-65 & $3.3 \pm 0.9$ & $3.8 \pm 0.6$ & .03 \\
\hline PSI & $157.6 \pm 30.6$ & $173.2 \pm 20.9$ & .07 \\
\hline NHAP index & $3.3 \pm 0.95$ & $3.6 \pm 0.5$ & .12 \\
\hline SMART-COP & $4.7 \pm 1.7$ & $5.6 \pm 2.5$ & .2 \\
\hline SOAR & $2.6 \pm 0.8$ & $3 \pm 0.8$ & .15 \\
\hline $\begin{array}{l}\text { CRP }=\text { C-reactive } \\
\text { PCT }=\text { procalcitoni } \\
\text { CURB-65 = confus } \\
\text { PSI = pneumonia } \\
\text { NHAP = nursing ho } \\
\text { SMART-COP = sy } \\
\text { frequency, tachycar } \\
\text { SOAR = systolic bl }\end{array}$ & $\begin{array}{l}\text { ea nitrogen, breathing } \\
\text { index } \\
\text { quired pneumonia } \\
\text { lood pressure, multil } \\
\text { fusion, oxygen, arter } \\
\text { essure, oxygen, age }\end{array}$ & $\begin{array}{l}\text { hcy, blood pressure, } \\
\text { olvement, albumin, b } \\
\text { breathing frequency }\end{array}$ & of age \\
\hline
\end{tabular}

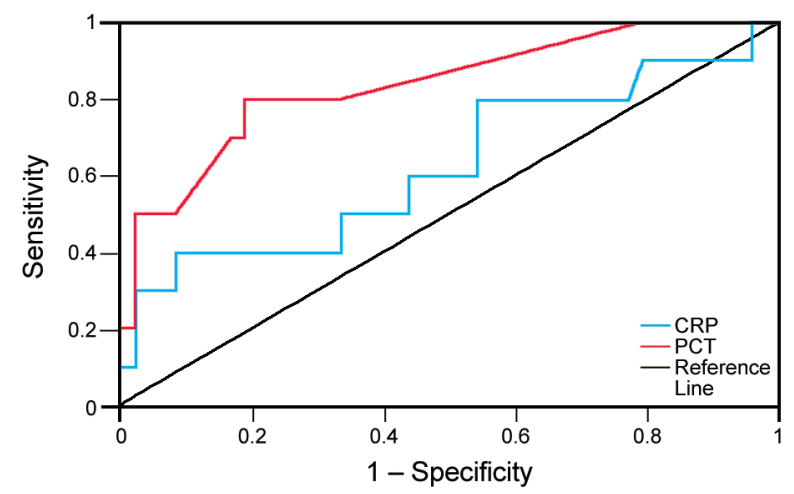

Fig. 4. Receiver operator characteristic curve of C-reactive protein and procalcitonin to predict inpatient mortality from nursing home acquired pneumonia.

Pneumonia is the most common cause for hospitalization and death among residents in nursing homes. ${ }^{1}$ Early diagnosis of NHAP remains a challenge. Institutionalized subjects frequently present atypical clinical signs and symptoms of pneumonia. ${ }^{2}$ Depressed mental status, congestive heart failure, COPD, prior use of antibiotics, a subject's lack of corporation, and poor quality of chest radiographs may complicate the diagnosis. The presence of a new pulmonary infiltrate in a chest $\mathrm{x}$-ray is considered indicative for diagnosing pneumonia. However, many nursing home residents who are transferred to acute care departments with acute respiratory illness and pathological findings in radiological imaging do not have NHAP. The differential diagnosis in the majority of such cases includes noninfectious cardiac and pulmonary disorders, the clinical presentation of which may resemble pneumonia. The delayed correct diagnosis results in delayed treatment, which contributes to higher mortality rates. ${ }^{17}$ Therefore, easily avail-

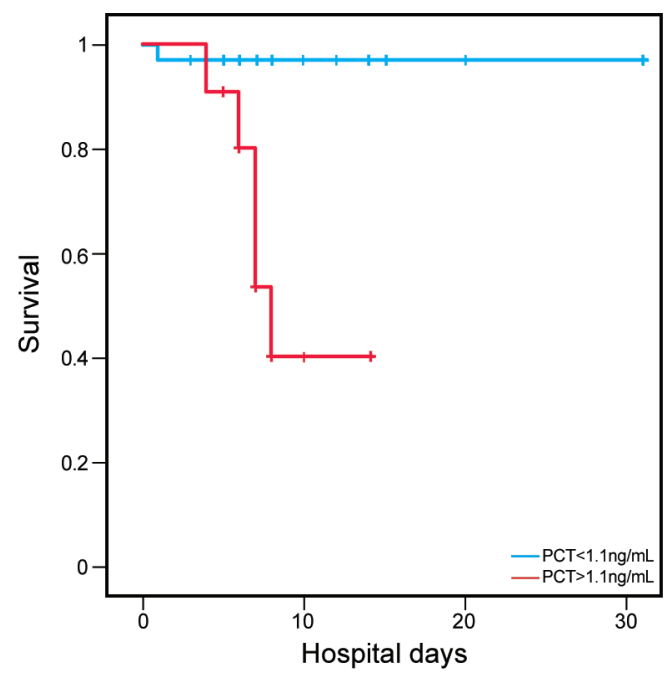

Fig. 5. Analysis of procalcitonin levels in subjects with nursing home acquired pneumonia.

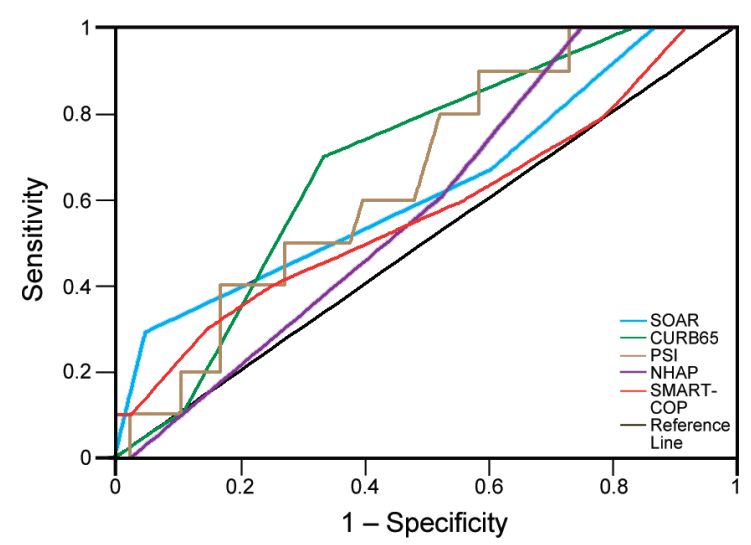

Fig. 6. Receiver operator characteristic curve of CURB-65 (confusion, urea, respiratory rate, blood pressure and age $>65$ ), pneumonia severity index (PSI), nursing home acquired pneumonia (NHAP) index, SMART-COP (systolic blood pressure, multilobar involvement, albumin, respiratory rate, tachycardia, confusion, oxygen, arterial $\mathrm{pH}$ ) and SOAR (systolic blood pressure, oxygen, age $>65$ and respiratory rate) scoring systems to predict inpatients mortality from nursing home acquired pneumonia.

able, objective, sensitive, and specific biomarkers for a rapid diagnosis and differential diagnosis of NHAP are important.

Clinical infection scores and biomarkers have been shown to be useful in the early diagnosis of CAP and $\mathrm{VAP}^{3-5,18}$; however, their value in the diagnosis and prognosis of NHAP is unclear. Our data show that the combination of fever, shortness of breath, cough, and raised WBC count was less accurate for the diagnosis of NHAP $(P=.15)$ and that the diagnosis of infection is not always clear in the acute setting. In our study, we evaluated the role of C-reactive protein and procalcitonin in the early diagnosis of pneumonia in a heterogeneous group of nurs- 
ing home residents. The results are promising because C-reactive protein and procalcitonin were significantly higher in Group A compared with Group B $(P<.001)$. In addition, the diagnostic accuracy of serum $\mathrm{C}$-reactive protein and procalcitonin was higher compared with the combination of clinical characteristics and raised WBC count. C-reactive protein and procalcitonin levels can be useful tools in deciding whether to initiate or withhold empirical antibiotic treatment in nursing home residents with acute respiratory illness.

Previous studies showed that CPIS was useful in the diagnosis of CAP and VAP. ${ }^{6,7}$ The assessment of CPIS is simple, calculating 6 variables (tracheal secretions, chest $\mathrm{x}$-ray findings, temperature, $\mathrm{WBC}, \mathrm{P}_{\mathrm{aO}_{2}} / \mathrm{F}_{\mathrm{IO}_{2}}$ ratio, and microbiology). Tracheal secretions can be obtained via suction from subjects having difficulty secreting their sputum. In agreement with previous studies, we found that CPIS is a reliable tool in the early diagnosis of NHAP because subjects diagnosed with NHAP had significantly higher CPIS scores upon admission and after $48 \mathrm{~h}$ compared with subjects diagnosed with other pulmonary disorders $(P<.001)$.

The results from our study show that Streptococcus pneumoniae was the most common pathogen among subjects diagnosed with NHAP. Whereas methicillin-resistant Staphylococcus aureus presented $7.4 \%(n=2$ of 27$)$ of all isolates, there were higher incidents of Gram-negative pathogens ( $40 \%, n=11$ of 27). Although these findings differ from those in previous studies, ${ }^{1,19,20}$ we acknowledge that this is likely to reflect the relatively small number of patients in our study. Furthermore, the results from our study indicate a relationship between the levels of C-reactive protein and procalcitonin and the causative pathogens. More precisely, NHAP caused by Gram-positive pathogens was accompanied by greater levels of Creactive protein and procalcitonin compared with NHAP caused by Gram-negative pathogens. In contrast, Charles et $\mathrm{al}^{19}$ found that procalcitonin levels were higher in cases with Gram-negative compared with Gram-positive bacteremia, whereas there was no difference in C-reactive protein levels between the 2 study groups. However, in the latter study, data from a heterogeneous population were analyzed, including patients from an ICU, with a broad spectrum of medical or surgical infections with bacteremia, whereas only subjects with NHAP were enrolled in our study.

Previous studies showed that pneumonia severity scores, functional status, comorbidities, nutritional status, serum albumin levels, and C-reactive protein are significant prognostic factors of mortality from NHAP. 1,2,8-10,12,17, 20-24 The results from our study showed that CURB-65 and the pneumonia severity index were more accurate in predicting in-hospital mortality from NHAP compared with the other pneumonia severity scores. The findings are in agreement with previous studies ${ }^{10,20,24}$ but in contrast to other studies. ${ }^{8-10,12}$ These differences are likely to reflect the fact that most nursing home residents have a worse general condition due to comorbidities, making the estimation of the risk of death based on clinical parameters difficult and less accurate. $^{2}$

C-reactive protein and procalcitonin have been described as reliable markers for the diagnosis and prognosis of CAP and VAP with contradictory results, especially for VAP. ${ }^{3-6,24-30}$ According to American Thoracic Society/Infectious Diseases Society of America guidelines, NHAP is considered to be a distinct group of respiratory infections with more similarities with hospital acquired pneumonia and VAP than with CAP. ${ }^{15}$ However, there are only limited data in the literature on the role of biomarkers in NHAP. Arinzon et al ${ }^{23}$ found that serum C-reactive protein levels at the time of diagnosis of pneumonia predict the severity and outcome of NHAP. However, the latter did not compare the C-reactive protein levels in patients diagnosed with NHAP and in patients with other respiratory diseases, the study population was small, and procalcitonin levels were not measured.

The role of procalcitonin in prognosis and antibiotic guidance has been studied in CAP, VAP, and pneumonia in elderly patients but not in NHAP. In our study, serum procalcitonin levels $<1.1 \mathrm{ng} / \mathrm{mL}$ upon admission were associated with an improved survival. These results are in agreement with previous studies regarding the value of procalcitonin in the prognosis of severe CAP, $24,25,29,30$ where a similar cutoff value of procalcitonin $(<0.95 \mathrm{ng} /$ $\mathrm{mL}$ ) was associated with a favorable outcome.

Our study presents 3 main limitations: (1) This was a single-center study, and the number of subjects was limited; (2) no documented cases of NHAP caused by L. pneumophila, Mycoplasma pneumoniae, protozoa, or parasites were enrolled in Group A; and (3) do-not-resuscitate orders were not part of the exclusion criteria because medical intervention would be identical to other subjects, apart from intubation, mechanical ventilation, or use of vasopressors.

\section{Conclusions}

CPIS, procalcitonin, and C-reactive protein are reliable for the diagnosis of NHAP. C-reactive protein appeared to perform better in diagnosing NHAP, whereas procalcitonin demonstrated a better correlation in predicting inhospital mortality. Procalcitonin and C-reactive protein levels were significantly higher in subjects with NHAP from Gram-positive pathogens. Serum procalcitonin levels $>1.1 \mathrm{ng} / \mathrm{mL}$ upon admission were an accurate independent predictor of in-hospital mortality from NHAP. In subjects with NHAP, CURB-65 and the pneumonia severity index performed better than the other proposed pneumonia 


\section{Pneumonia Severity Scores in Nursing Home Acquired Pneumonia}

severity scoring systems in predicting in-hospital mortality. Future research should focus on a possible role for a procalcitonin-based diagnostic and therapeutic strategy in NHAP.

\section{REFERENCES}

1. El-Solh AA, Niederman MS, Drinka P. Nursing home acquired pneumonia: a review of risk factors and therapeutic approaches. Curr Med Res Opin 2010;26(12):2707-2714.

2. Marrie TJ. Pneumonia in the long-term-care facility. Infect Control Hosp Epidemiol 2002;23(3):159-164.

3. Woodhead M, Blasi F, Ewig S, Garau J, Huchon G, Ieven M et al. Guidelines for the management of adult lower respiratory tract infections-full version. Clin Microbiol Infect 2011 17(6 Suppl):E1E59.

4. Christ-Crain M, Schuetz P, Müller B. Biomarkers in the management of pneumonia. Expert Rev Respir Med 2008;2(5):565-572.

5. Rea-Neto A, Youssef NC, Tuche F, Brunkhorst F, Ranieri VM, Reinhart K, Sakr Y. Diagnosis of ventilator-associated pneumonia: a systematic review of the literature. Crit Care 2008;12(2):R56.

6. Porfyridis I, Plachouras D, Karagianni V, Kotanidou A, Papiris SA, Giamarellou H, Giamarellos-Bourboulis EJ. Diagnostic value of triggering receptor expressed on myeloid cells-1 and C-reactive protein for patients with lung infiltrates: an observational study. BMC Infect Dis 2010;10:286.

7. Fartoukh M, Maitre B, Honoré S, Cerf C, Zahar JR, Brun-Buisson C. Diagnosing pneumonia during mechanical ventilation: the clinical pulmonary infection score revisited. Am J Respir Crit Care Med 2003;168(2):173-179.

8. Fang WF, Yang KY, Wu CL, Yu CJ, Chen CW, Tu CY, Lin MC. Application and comparison of scoring indices to predict outcomes in patients with healthcare-associated pneumonia. Crit Care 2011; 15(1):R32.

9. British Thoracic Society, Myint PK, Kamath AV, Vowler SL, Maisey DN, Harrison BD. Severity assessment criteria recommended by the British Thoracic Society (BTS) for community-acquired pneumonia (CAP) and older patients. Should SOAR (systolic blood pressure, oxygenation, age and respiratory rate) criteria be used in older people? A compilation study of two prospective cohorts. Age Ageing 2006;35(3):286-291.

10. El-Solh AA, Alhajhusain A, Abou Jaoude P, Drinka P. Validity of severity scores in hospitalized patients with nursing home acquired pneumonia. Chest 2010;138(6):1371-1376.

11. Charles PG, Wolfe R, Whitby M, Fine MJ, Stirling R, Wright AA et al. SMART-COP: a tool for predicting the need for intensive respiratory or vasopressor support in community-acquired pneumonia. Clin Infect Dis 2008;47(3):375-384.

12. Naughton BJ, Mylotte JM, Tayara A. Outcome of nursing homeacquired pneumonia: derivation and application of a practical model to predict 30-day mortality. J Am Geriatr Soc 2000;48(10):12921299.

13. Oken MM, Creech RH, Tormey DC, Horton J, Davis TE, McFadden ET, Carbone PP. Toxicity and response criteria of the Eastern Cooperative Oncology Group. Am J Clin Oncol 1982;5(6):649-655.

14. Pugin J, Auckenthaler R, Mili N, Janssens JP, Lew PD, Suter PM. Diagnosis of ventilator-associated pneumonia by bacteriologic analysis of bronchoscopic and nonbronchoscopic "blind" bronchoalveolar lavage fluid. Am Rev Respir Dis 1991;143(5):1121-1129.
15. American Thoracic Society and Infectious Diseases Society of America. Guidelines for the management of adults with hospital-acquired, ventilator-associated, and healthcare-associated pneumonia. Am J Respir Crit Care Med 2005;171(4):388-416.

16. Mandell L, Wunderink R, Anzueto A, Bartlett J, Campbell D, Dean $\mathrm{N}$ et al. Infectious Diseases Society of America/American Thoracic Society consensus guidelines on the management of communityacquired pneumonia in adults. Clin Infect Dis 2007;44(2 Suppl):2772.

17. Brito V, Niederman MS. How can we improve the management and outcome of pneumonia in the elderly? Eur Respir J 2008;32(1):1214.

18. Luyt CE, Combes A, Reynaud C, Hekimian G, Nieszkowska A, Tonnellier $\mathrm{M}$ et al. Usefulness of procalcitonin for the diagnosis of ventilator-associated pneumonia. Intensive Care Med 2008;34(8): 1434-1440.

19. Charles PE, Ladoire S, Aho S, Quenot JP, Doise JM, Prin S et al. Serum procalcitonin elevation in critically ill patients at the onset of bacteremia caused by either Gram negative or Gram positive bacteria. BMC Infect Dis 2008 8:38.

20. Polverino E, Dambrava P, Cillóniz C, Balasso V, Marcos MA, Esquinas $\mathrm{C}$ et al. Nursing home acquired pneumonia: a 10 year singlecentre experience. Thorax 2010;65(4):354-359.

21. Muder RR, Aghababian RV, Loeb MB, Solot JA, Higbee M. Nursing home acquired pneumonia: an emergency department treatment algorithm. Curr Med Res Opin 2004;20(8):1309-1320.

22. Ma HM, Tang WH, Woo J. Predictors of in-hospital mortality of older patients admitted for community-acquired pneumonia. Age Ageing 2011;40(6):736-741.

23. Arinzon Z, Peisakh A, Schrire S, Berner Y. C-reactive protein (CRP): an important diagnostic and prognostic tool in nursing-home-associated pneumonia. Arch Gerontol Geriatr 2011;53(3):364-369.

24. Heppner HJ, Bertsch T, Alber B, Esslinger AS, Dragonas C, Bauer JM, Sieber CC. Procalcitonin: inflammatory biomarker for assessing the severity of community-acquired pneumonia-a clinical observation in geriatric patients. Gerontology 2010;56(4):385-389.

25. Masiá M, Gutiérrez F, Shum C, Padilla S, Navarro JC, Flores E, Hernández I. Usefulness of procalcitonin levels in community-acquired pneumonia according to the patients outcome research team pneumonia severity index. Chest 2005;128(4):2223-2229.

26. Boussekey N, Leroy O, Georges H, Devos P, d'Escrivan T, Guery B. Diagnostic and prognostic values of admission procalcitonin levels in community-acquired pneumonia in an intensive care unit. Infection 2005;33(4):257-263.

27. Hillas G, Vassilakopoulos T, Plantza P, Rasidakis A, Bakakos P. $\mathrm{C}$-reactive protein and procalcitonin as predictors of survival and septic shock in ventilator-associated pneumonia. Eur Respir J 2010; 35(4):805-811.

28. Pávoa P, Salluh JI. Biomarker-guided antibiotic therapy in adult critically ill patients: a critical review. Ann Intensive Care 2012; 2(1):32.

29. Boussekey N, Leroy O, Alfandari S, Devos P, Georges H, Guery B. Procalcitonin kinetics in the prognosis of severe community-acquired pneumonia. Intensive Care Med 2006;32(3):469-472.

30. Krüger S, Ewig S, Marre R, Papassotiriou J, Richter K, von Baum H et al. Procalcitonin predicts patients at low risk of death from community-acquired pneumonia across all CRB-65 classes. Eur Respir J 2008;31(2):349-35. 